\title{
1 Measuring and Modeling Russian Newspaper Coverage of Climate Change
}

3 Abstract

As a significant emitter of greenhouse gases and a country rich in fossil fuels, Russia plays a crucial role in achieving a comprehensive solution to climaterelated challenges. Yet, Russia's official position on climate change has varied considerably since the beginning of global negotiations, with the country playing everything from policy leader to laggard. While there are a number factors that shape domestic policy positions on climate change, this study offers a comprehensive investigation of newspaper coverage on climate change in Russia. How have Russian newspapers discussed the issue since the Yeltsin era? We approach this question by compiling the largest data set of Russian newspaper coverage to date, which includes 11,131 climate-related articles from 65 papers over a roughly 35 year period. After introducing a "computer assisted" approach to measure the core themes running through climate change coverage, we statistically evaluate the national- and newspaper-level factors associated with how coverage is framed, focusing attention on 23 high circulation papers over the period from 2000 to 2014 . We find that national-level predictors - particularly economic conditions - are highly influential of whether climate change is covered and how the issue is framed, while paper-level factors such as the presence of energy interest and ownership structure also have notable effects. Overall, this study offers a rich data set and an array of methods to better understand the drivers of climate communication in Russia.

4 Keywords: climate change, newspaper coverage, Russia, text analysis

\section{1. Introduction}

As the world's fourth largest greenhouse gas (GHG) emitter, Russia remains a vital piece of any comprehensive and effective plan to mitigate the harmful effects of climate change (UNFCCC 2014). Although Russia played an ambiguous but, nevertheless, pivotal role in the Kyoto Protocol's acceptance (Afionis and Chatzopoulos 2010, Andonova 2008), its current commitment to reducing GHG emissions remains unclear. Recently, Russia announced its withdrawal from the second commitment period to the Kyoto Protocol (Bedritsky 2014), eliminated expenses on energy efficiency from the 2015 federal budget (Davydova 2015), and released a set of "intended nationally determined contributions" (INDCs) that could increase GHG emissions considerably above current levels by 2030 
(Levin and Damassa 2015). It is thus an open question as to whether Russia will be a leader or laggard in the pursuit to negotiate and implement an effective solution to challenges posed by anthropogenic global warming.

Understanding Russia's position on climate change policy requires careful consideration of the international and domestic factors that promote or impede cooperation. While a diverse array of factors have been suggested in the literature, media coverage is seen to play a crucial role in various aspects of the climate debate. First, considering the agenda-setting function of mass media (McCombs and Shaw 1972) and its influence in shaping public opinion in Russia (White and Oates 2003), news coverage offers a useful means to discern domestic support for climate change action. Discerning public opinion is crucial, as only roughly 3 in 10 Russians believe that climate change is a serious problem and overall concern has decreased by roughly $10 \%$ since 2010 (Stokes et al. 2015). Second, mass media also play an important role in translating state views of climate change to national and international audiences, particularly in nations with limited press freedom (Bell 1994, Boyce and Lewis 2009, Boykoff 2012, Butler and Pidgeon 2009, Davidsen and Graham 2014, Dirikx and Gelders 2009, Doulton and Brown 2009, Grundmann and Scott 2012, Lockwood 2009, Lyytimäki 2011). Having a long history of close relations with the state, Russian media coverage often serves as a window into official government positions on climate policy and thus inform interested parties on how to understand Russia's position at future climate change negotiations (Poberezhskaya 2015).

Against this backdrop, we examine the evolution of Russian media discourse on global warming in the post-Soviet era. Although a number of studies examine climate change-related communication in Russia (Poberezhskaya 2014; Tynkkynen 2010; Wilson Rowe 2009; Yagodin 2010), past work is limited both in terms of time period under study and the number of media outlets examined. We contribute to the literature by 1) compiling the largest corpus of Russian newspaper coverage on the issue of climate change, collecting 11,131 relevant articles from 65 newspapers over the time period from May, 1980 to May, 2014; 2) introduce a computer assisted approach to content analysis appropriate for a large corpus of documents; and 3) offer a multi-level statistical framework for assessing the drivers of media coverage in Russia. To our knowledge, this study offers the first large-scale analysis of Russian print media coverage of climate change that statistically evaluates how both paper and national level characteristics shape climate discourse. Overall, the evidence suggests that economic conditions are more likely than political factors to explain climate coverage, while paper-specific characteristics - such as energy interests, ownership structure, and ideology - also play a role. Our study thus questions arguments on the predominant influence of political personalities over climate discourse in the country and suggests a range of alternative explanations for the media approach to the problem. 


\section{Media Coverage of Climate Change in Russia: Theory and Hy- potheses}

The importance of mass media in communicating climate change risks has been stressed by a variety of scholars (Bell 1994; Boyce and Lewis 2009; Boykoff 2012; Butler and Pidgeon 2009; Carvalho and Burgess 2005; Davidsen and Graham 2014; Dirikx and Gelders 2009; Doulton and Brown 2009; Grundmann and Scott 2012; Lockwood 2009; Lyytimäki 2011; Olausson 2009). Often the first point of contact between public and climate science, the media is tasked with the crucial role of interpreting the somewhat abstract and difficult to comprehend scientific discourse (Beck 1992; Boykoff and Boykoff 2007; Carvalho 2007; Nelkin 1987 ; Rapley and De Meyer 2014). Olausson and Berglez (2014 p. 251) suggest that scholarly investigations of media coverage of climate change issues should expand inquiries of the power dynamics within national media discourses: "it is vital to examine who becomes the 'primary definer' of the climate issues." In other words, it is crucial to identify the role of mass media in "setting the agenda" (Newell 2006; Boykoff and Boykoff 2004; Carvalho and Burgess 2005) and "framing" the debate around the policy and science of global warming (Boykoff 2007a, Boykoff and Rajan 2007, Carvalho 2007).

The media's ability to define the issue of climate change does not take place in a vacuum - mass media both shapes and is shaped by social, political, and economic forces. Bailey et al. (2014 p. 199) note, in their comparative study of Spanish and American media coverage of climate change, that "media portrayals of climate (un)certainty are steeped in the historically contingent space of ideology, culture, and politics, where various actors and institutions battle to shape public understanding and engagement." When studying the Russian case, one observes a historical progression marked by an ambiguous relationship between the media, the state, and key economic actors. Towards the end of the 1980s and in the early 1990s, the media became an influential actor in the regime change process through its increasingly open criticism of the old regime and growing support of emerging political actors (Coyne and Leeson 2009, Mickiewicz 1999, Strovskiy 2011, Voltmer 2000). During the presidency of Boris Yeltsin, the mass media's political role swung from that of active support for the ruling elite to extreme criticism of some of its more questionable political decisions (for example, the war in Chechnya, see Grabel'nikov 2001). Furthermore, Yeltsin's presidency was marked by the growth in power of the so-called "oligarchs" and their expanding control over the media market (Lipman and McFaul 2001; Zassoursky 2001). The dawn of the Putin era in Russian politics further signified a move towards the centralisation of the media market and the re-establishment of state authority in the public discourse (Becker 2004; Zassoursky 2004). Moreover, when studying media coverage of climate change, it is important to consider that "oligarchs" and the state have close connections to the Russian fossil fuel industry, with such "gas giants" as Gazprom owning a vast number of national media outlets (Toepfl 2013). As will be discussed below, the interests of such owners are expected to shape newspaper coverage of climate change. 


\subsection{Presidency and Kremlin loyalty}

Richard Sakwa (2010: viii) argues that Russia is "a dual state" where "the legal-normative system based on constitutional order is challenged by shadowy arbitrary arrangements." For example, it can be argued that power in the country is disproportionately skewed towards the president or towards key political figures (for example, Putin's personal domination over Russian politics (Hanson 2010)). Regarding Russia's climate policy, it has been suggested that stagnation in its development can be explained by Putin's personal negative attitude towards this environmental problem (Henry and Sundstrom 2012). At the same time, the recent positive change in national climate affairs could be attributed to Medvedev's striving for a green economy and modernisation (Monaghan 2012). Therefore, we suggest that while pro-Kremlin newspapers are expected to closely follow the state's agenda on climate change, their coverage will adjust depending on whether Putin or Medvedev is in power. Where Putin's presidency would have a negative impact on the quantity of articles and qualitatively on their content, the discussion will steer away from the sensitive issues of domestic politics and emphasize the costs of climate action. Under Medvedev's leadership, we expect to see an increase in coverage with more discussions dedicated to energy efficiency, international cooperation, domestic politics as well as science.

\subsection{Newspaper ownership, interests and ideology}

As Andonova (2008) argues, we cannot oversimplify Russia's political process by narrowing it down to the changes at the executive level. Therefore, we need to consider a range of other societal and newspaper-level variables that may determine newspaper attention to climate change. By examining the UK quality press, (Carvalho 2007 p. 223) discusses how the media representation of climate change, "is strongly entangled with ideological standpoints." In Russia, the ideological orientation of the newspapers has to be treated with caution as the distinction between left, centre and right are often blurred and need to be treated in consideration with media ownership structures and their governmental links. That said, as demonstrated by previous research on the influence of the newspapers' political leanings on their approach to climate change coverage (Carvalho and Burgess 2005, Carvalho 2007, Poberezhskaya 2015), we can suggest that oppositional newspapers (far-right and far-left) owned by nongovernmental political parties will be very vocal across various topics as they can use climate change as an opportunity to criticise the state. Similar expectations (but to a lesser degree) could be expected from the newspapers whose majority shareholders are journalists, especially those on the political left. At the same time, the media outlets belonging to the political right and centre should be quite reserved in their climate coverage and likely eschew economically problematic areas (e.g. Russia's international obligations or fossil fuel industry). We expect that avoidance will also be intensified if a newspaper is owned by business interests or if it state-owned. At the same time, considering the nature of the climate change problem, we hypothesise that newspapers with energy interests will avoid discussing the problem in the context of fossil fuels or renewable energy 
development, and should also be less likely to discuss climate change overall. It should be noted that, throughout the studied years, the Russian newspapers' market has been dominated by the business led ownership structure with various degrees of their relations with the state (Lehtisaari 2015).

\subsection{National economic performance}

It has been argued that during economic recessions people tend to privilege financial stability over environmental security (e.g. Inglehart 1995, Scruggs and Benegal 2012, Shum 2012). For decades this has been the case for Russia where the environment has been persistently sacrificed to economic development (Henry 2010). Therefore, we can assume that economic crises (e.g. high inflation) should reduce newspaper attention to climate change, as the national economic well-being would take precedence. However, the state of the economy might also have an impact on what themes are focused on when climate change is indeed discussed. We posit that poor economic performance should be positively associated with discussion of climate change in the context of economic opportunities (e.g. Arctic development, international cooperation and energy efficiency).

\subsection{Natural disasters}

There is some (but limited) evidence in the literature linking the influence of extreme weather events to media coverage of climate change (Shanahan and Good 2000, Boykoff and Boykoff 2007, Boykoff 2007b, Schäfer et al. 2014). However, impacts of natural hazards on attention to global warming seem to also depend on various social, political, economic, and other country-specific factors. Current understanding suggests heterogeneous effects, with cross-national variation in the intensity of the negative consequences of climate change on public discourse (e.g. Schäfer et al. 2014, Schmidt et al. 2013). However, there is evidence which indicates that warm temperature anomalies might impact individual attitudes toward climate change (Li et al. 2011, Zaval et al. 2014). Considering Russia's growing climate vulnerability, we suggest that climate change related natural hazards should increase media attention to global warming. The 2010 Russian heatwave, which resulted in the deaths of over 55,000 people and an estimated economic loss of $\$ 15$ billion (Barriopedro et al. 2011), was a catastrophic event that led to a strengthening of ecological groups in Russia (Yanitsky 2012). We therefore expect that when natural disasters occur, newspaper coverage of climate change should be more likely.

\section{Measuring Russian Newspaper Coverage of Climate Change, 2000- 2014}

This study extends previous work on media coverage of climate change in Russia by incorporating an extensive list of Russian newspapers over a considerable period of time. To create the corpus, we retrieved newspaper articles 
which contained the terms "climate change", "global warming", or "greenhouse effect" from the Eastview Russian Central Newspapers database (UDB-COM). This resulted in the identification of 11,131 relevant articles from 65 newspapers. The temporal coverage of the corpus is large, ranging from 3 May 1980 to 7 May 2014. The full list of newspapers and article counts, along with an illustration of temporal variation in coverage for the entire period are presented in ??. Most newspapers entered the Eastview database in the late 1990s and early 2000s. Estimates of attention to climate change by the Russian press are therefore reliable starting around 2000. It is for this reason that the analysis conducted in Section 4 relies on 6,527 articles from the 23 most circulated newspapers over the period Q1/2000-Q2/2014. Specifically, we focus the study on a sample of papers with moderate to high circulation counts, ranging from 85,000 (the socialpolitical weekly magazine Itogi) to a maximum observed count of 2,985,000 (the national popular weekly Argumenty $i$ fakty). We expect that newspapers with very large circulation figures are influential due to massive exposure and that newspapers with average circulations are likely to have more narrow audiences. However, these somewhat smaller papers (e.g. Kommersant) are also likely to be influential since they are more likely to target "elites" and opinion leaders.

It is also important to note the potential limitations associated with focusing on newspapers to measure media coverage. As in many other countries around the world, the majority of Russians get their news from television, with over $90 \%$ of Russians tuning in each week (Broadcasting Board of Governors 2014, Deloitte CIS Research Centre 2016). Moreover, consistent with international trends in media consumption, the importance of online news has increased steadily overtime, particularly among younger individuals and those living in urban areas (Ibid). At the same time, print media remains an important source of news in general and political news in particular, with over $50 \%$ turing to newspapers and magazines for their news each week (Deloitte CIS Research Centre 2016).

Figure 1 displays quarterly counts of climate change related articles for the 23 most circulated Russian newspapers. Several features of aggregate media coverage based on the corpus are worth noting. Coverage of climate change in the Russian press maintained a steady increase until 2007, when we can observe a significant spike in attention. This finding is somewhat unexpected, as existing literature on Russian media coverage of climate change focuses on the period around 2009; prior years such as 2007 have been relatively ignored. Following a brief drop in coverage after 2007, there is a renewed spike in attention over the 2009-2010 period (Copenhagen meeting and 2010 Russian heat wave), which is then followed by a steady decrease in coverage. This attention pattern, more or less, maps well with coverage rates from major American newspapers (Boykoff et al. 2015). However, as is clear from the plot, in terms of absolute coverage, Russian newspapers have devoted strikingly low attention to the issue when compared to the American press. Notably, the New York Times has published more climate change related articles than all prominent Russian papers combined for most of the 2000-2014 period. 


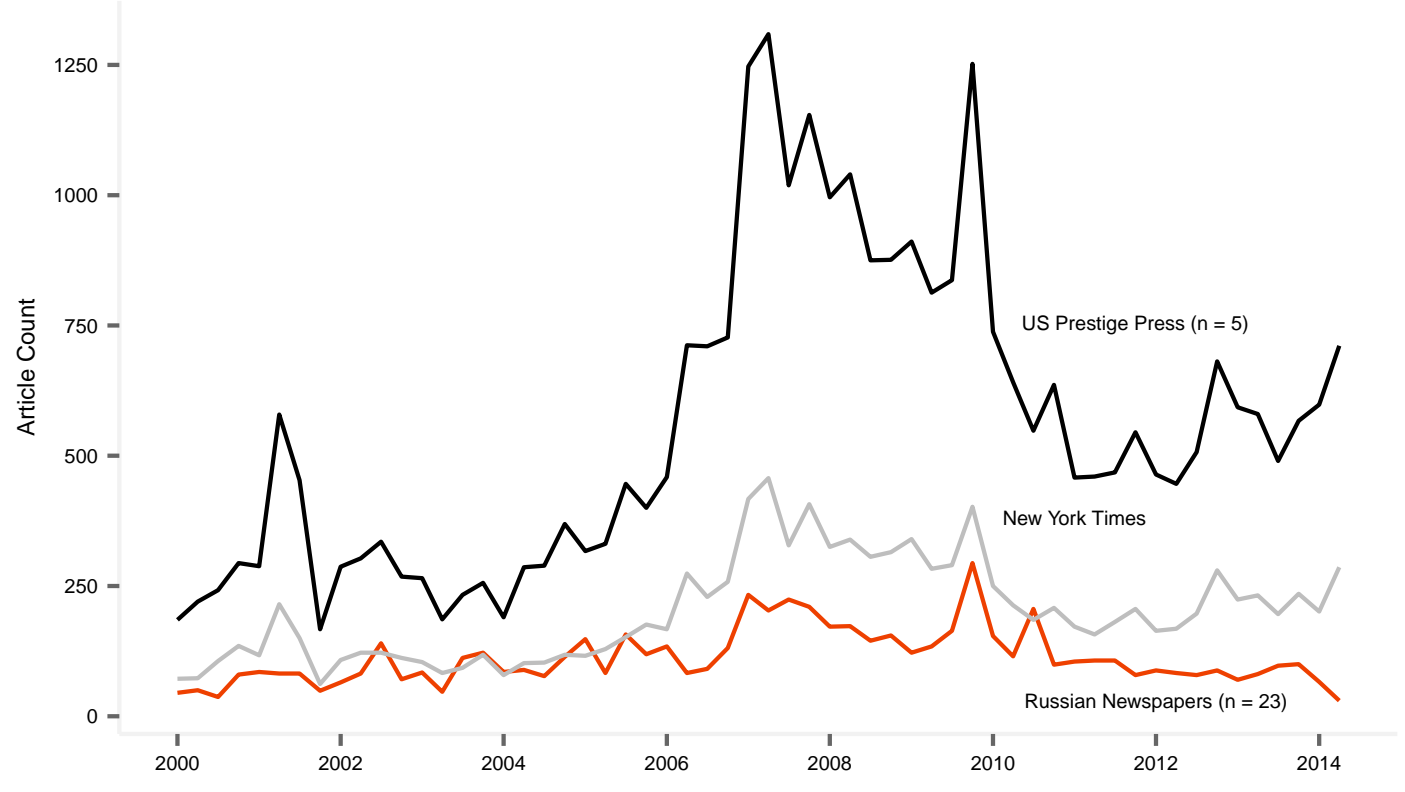

Figure 1: The number of newspaper articles that mention climate change over time. Displays quarterly counts of climate change related articles for the US "prestige press" (Washington Post, Wall Street Journal, New York Times, USA Today and Los Angeles Times) [black], the New York Times [grey], and the 23 most prominent Russian newspapers based on circulation [orange]. US newspaper data are derived from Boykoff et al. (2015). See ?? for a detailed list of the most prominent Russian newspapers.

\subsection{Measuring climate-related themes: computer "assisted" content analysis}

While aggregate trends offer some insight into climate-related coverage, the obvious next question centers on what themes are prevalent in Russian newspapers. Past content analyses of climate change coverage rely almost exclusively on traditional methods based on human coders (Antilla 2008, Bailey et al. 2014, Olausson 2009, Shrestha et al. 2014, Taylor and Nathan 2002). These methods are, however, extremely costly - in terms of both time and effort - and thus researchers are often forced to make important trade-offs, either constraining temporal coverage (c.f., Nissani 1999, Painter and Ashe 2012) or focusing on thoroughly reading a smaller, more manageable set of documents (c.f., Elsasser and Dunlap (2013), Dunlap and Jacques (2013)).

Yet, if traditional content analytic methods do not scale to meet the needs of scholars of climate communication, it is essential to identify approaches that do. More recently, scholars have examined the "promise and pitfalls" of automated classification methods across a range of common tasks in the social sciences (Grimmer and Stewart 2013), and for classifying news story content in 
particular (Ali et al. 2010, Young and Soroka 2012). The promise of computational methods is clear: they offer a reliable means to classify the primary topics or themes for large corpora of text (Mikhaylov et al. 2012). The drawback of computational methods, however, is that considerable effort must go into ensuring model validity (Quinn et al. 2010). In short, important trade-offs must be considered irrespective of whether an analyst chooses to employ traditional or automated forms of content analysis.

We argue that much may be gained by combining aspects of both methodologies. Consistent with recent literature on the use of text analytic models in the social sciences, our approach views computational methods as assisting, not replacing, traditional techniques (Grimmer and King 2011). Grimmer and Stewart (2013 p. 2) summarize this position quite well:

"the complexity of language implies that automated content analysis methods will never replace careful and close reading of texts. Rather, the methods that we profile here are best thought of as amplifying and augmenting careful reading and thoughtful analysis." (emphasis in original)

As such, we analyze key themes in climate-related articles using an approach that strikes a balance between traditional methods based on human coding and recent advances in the field of natural language processing. Specifically, we employ the following three-step procedure:

1. we first "augment" the corpus using an unsupervised algorithm to identify meaningful topics (or clusters) in Russian newspapers and utilize the estimated topics to identify a small subset of documents that require a "careful and close reading;"

2. use the results of step 1 and traditional inductive content analytic methods to code a sample of documents into a set of valid, reliable, and substantively meaningful themes;

3 . combine the results from steps 1 and 2 to develop a computational procedure for classifying the primary themes in the corpus, validating the model using common classification performance metrics (i.e., accuracy, precision, and recall).

The remainder of this section briefly outlines our approach - a fuller description of all of the methods described in this section is available in the online appendix.

\subsubsection{Reducing dimensionality via unsupervised learning}

We begin with the observation that while reading 11,131 articles is practically infeasible, carefully assessing 100 key "topics" is much more attainable. As a first step, then, we need a method to reduce our overall corpus to a core set of topics or themes. To achieve this objective, we utilize the well-known latent Dirichlet allocation (LDA) model originally proposed in Blei et al. (2003). Viewing each document as a finite mixture of "topics" (i.e. meaningful clusters 
of words), the LDA models the random process responsible for "generating" a particular text (see the supplemental appendix for technical details). While the Bayesian methods used to produce "topics" are a bit involved (see the appendix for details), the important point is that the LDA has been shown to preform well in a wide range of areas, from population biology to information retrieval, and thus provides a suitable method our data reduction task (Blei 2012 see).

The results from estimating a 100 topic model are available in the appendix (see Table ??). Analyzing all 100 topics, however, is unwieldy and many topics deal with similar overarching themes. As such, there are substantive and practical benefits from further coding the topics into higher order themes that conform with key aspects of climate change coverage. To do this, we first categorize topics into topic families or "meta-topics" using the topic keywords and, more importantly, the descriptive labels derived from a careful read of the top 5 to 10 most probable documents. This procedure yielded a total of 23 substantive meta-topics which cover themes related to science, energy, economics, international and domestic politics, and society. A full list of these meta-topics are displayed in Table 1 along with the labels and identification numbers of each meta-topic's underlying topics, a measure of how often the meta-topic is sampled from the corpus (prevalence), and two classification accuracy scores which are discussed in detail in Section 3.1.2.

\subsubsection{Model validation}

A critical - if not the critical - step in any computer-assisted approach to content classification is model validation. If the specified model is working well, then the predicted primary topic or topics should correspond to the categories assigned by human coders. To construct a manually annotated set of documents to use for purposes of validation, we relied on the standard operating procedure of "inductive" content analysis: we use a small (randomly selected) set of documents, classified the primary topic of each document using the 23 codes outlined in Table 1, discussed disagreements, and modified accordingly. More specifically, we repeated this inductive process until reliability was sufficiently high (Krippendorff's $\alpha \geq 0.80$ ). After ensuring sufficient reliability, each individual coder classified the primary topic of 225 documents, leaving a total of 450 manually annotated for validation purposes.

With a human-coded test set in hand, the next question is what criteria should be used to judge model validity. One approach is to draw on procedures commonly used to assess supervised learning problems, which include measuring some combination of classification accuracy, reliability, and precision. We rely on this approach here. Table 1 examines classification accuracy using the harmonic mean of precision and recall-i.e., the well-known and often used "F1 score". First, we compare the primary (or "top") topic suggested by the model to the primary topic identified by human coders. As demonstrated in Table 1, there is considerable variation in classification accuracy across the 23 categories, with the F1 score ranging from 0.84 (Health) to only 0.25 (Russian Cities). For the set of issues salient for the literature on Russian coverage of the climate 


\begin{tabular}{|c|c|c|c|c|}
\hline \multirow[t]{2}{*}{ Meta-Topic Label } & \multirow[t]{2}{*}{ Prevalence } & \multicolumn{2}{|c|}{ F1 Score } & \multirow[t]{2}{*}{ Underlying Topic Label [ID] } \\
\hline & & Top & Top 2 & \\
\hline Activism & 0.01 & 0.73 & 0.76 & Activism (Protests) [26], Earth Hour [30] \\
\hline Agriculture & 0.01 & 0.59 & 0.74 & Food security $[42]$ \\
\hline Arctic politics & 0.01 & 0.82 & 0.87 & Arctic geopolitics [4] \\
\hline Climate impacts & 0.08 & 0.54 & 0.76 & $\begin{array}{l}\text { Water resources [27], Sea level rise [31], Archeology [35], } \\
\text { Housing [36], Wild life [41], Sea life [69], } \\
\text { Climate impacts (Mountains and glaciers) [73], } \\
\text { Climate consequences (Scientific forecast) [90] }\end{array}$ \\
\hline Climate science & 0.08 & 0.53 & 0.76 & $\begin{array}{l}\text { Space (Celestial bodies) [19], Carbon emissions [22], } \\
\text { Meteorology (Roshydromet) [24], Space science (Sun) [49], } \\
\text { Climate science (Ocean and climate) [62], Climate change (General) [84], } \\
\text { Science (Atmosphere) [93] }\end{array}$ \\
\hline Comparative politics & 0.04 & 0.63 & 0.68 & $\begin{array}{l}\text { Politics (Germany) [5], Politics (USA) [20], Politics (UK) [33], } \\
\text { Politics (South America) [54], Politics (Elections) [68], IR (China) [95] }\end{array}$ \\
\hline Disasters/Extreme weather & 0.07 & 0.72 & 0.83 & $\begin{array}{l}\text { Nature disaster (Forest fires) [0], Weather abnormalities [39], } \\
\text { Catastrophe (Futuristic predictions) [45], } \\
\text { Nature disaster (Hurricanes and floods) [58], } \\
\text { Catastrophe (Response/MCHS) [60], Winter abnormalities [66] }\end{array}$ \\
\hline Economy/Business & 0.08 & 0.47 & 0.67 & $\begin{array}{l}\text { Budgeting climate risk [1], Business [6], Economy general [29], } \\
\text { Corporate responsibility [59], Economy (Sustainable development) [86] }\end{array}$ \\
\hline Education & 0.01 & 0.36 & 0.67 & Education [23], Education (University competition) [52] \\
\hline Non-renewable energy & 0.02 & 0.61 & 0.81 & Energy (nuclear) [48], Energy (gas) [99] \\
\hline Renewable energy & 0.01 & 0.50 & 0.78 & Energy (Sustainable sources) [8] \\
\hline Energy efficiency & 0.02 & 0.43 & 0.67 & $\begin{array}{l}\text { Transport (Mostly aviation) [15], Transport (Cars) [17], } \\
\text { Energy (Efficiency, Emission reduction) [82] }\end{array}$ \\
\hline Health & 0.01 & 0.86 & 1.00 & Health $[47]$ \\
\hline Information technology & 0.004 & 0.50 & 0.80 & IT $[78]$ \\
\hline Int'l climate agreements & 0.03 & 0.84 & 0.91 & $\begin{array}{l}\text { Climate research (Russian-Belarusian) [10], Climate politics (COPs) [28], } \\
\text { Climate politics (Kyoto Protocol) [61] }\end{array}$ \\
\hline International politics & 0.05 & 0.53 & 0.71 & $\begin{array}{l}\text { UN (and Russia) [21], IR (ASIA-APEC) [34], Politics (EU) [53], } \\
\text { IR (Summits) [64], IR (Bilateral relations) [83] }\end{array}$ \\
\hline International security & 0.05 & 0.5 & 0.71 & $\begin{array}{l}\text { Russian national security [50], IR (Power politics) [55], Military [65], } \\
\text { Russian national security policy [67], IR (Security-conflicts) [94], } \\
\text { Russian foreign policy [98] }\end{array}$ \\
\hline Polar science & 0.01 & 0.75 & 0.89 & Antarctic [12], Arctic (Science) [89] \\
\hline Pollution & 0.01 & 0.29 & 0.46 & Env. protection (General pollution) [57], Env. protection (Air pollution) [87] \\
\hline Russian cities & 0.01 & 0.25 & 0.33 & Moscow $[79]$ \\
\hline Domestic climate politics & 0.04 & 0.49 & 0.74 & $\begin{array}{l}\text { Russian legislation [2], Medvedev's politics (Russian politics) [9], } \\
\text { Politics (Russian officials meet) [13], Russian mitigation legislature [40], } \\
\text { Russian diplomacy [51], Russian Politics (Ministries/docs) [91] }\end{array}$ \\
\hline Science (other) & 0.02 & 0.67 & 0.73 & Russian Science [71], Scientific discoveries (Genetics) [96] \\
\hline Society and culture & 0.10 & 0.44 & 0.70 & $\begin{array}{l}\text { Historical mysteries [3], Justice (crime) [7], Art (Film/music industry) [11], } \\
\text { Nobel Prize [88], Sport [97], Art (Music) [25], Philosophy [43], } \\
\text { Population growth [46], Fashion [63], USSR [70], Religion [74], } \\
\text { Literature [75], Politics and Society [76] }\end{array}$ \\
\hline
\end{tabular}

Table 1: Meta-topics and underlying topics within the newspaper corpus. This table provides the meta-topics determined using the methodological approach outlined in Section 3.1.1. "Prevalence" offers a rough measure of the importance of a meta-topic to the corpus and is measured using the proportion of words assigned by the LDA to a particular meta-topic over the sample period. The table presents two measures of predictive accuracy using the F1 score (see Section 3.1.2 for a full description). Lastly, we present the topic labels that underlie each meta-topic.

331 issue, meta-topics such as International Climate Agreements (0.84) and Arctic 332 Politics (0.82) are classified accurately, while other themes such as Domestic 33з Climate Politics (0.49) do not perform well. 
Yet judging an LDA model based only on the primary topic alone offers a conservative assessment of model accuracy. Even a cursory glance at articles in the Russian media corpus suggests that a single story will often discuss multiple climate-related themes, and it is not always easy for either human or computer to decide on what topic is "primary." To offer a less conservative assessment of predictive accuracy, we examine whether the model classifies the human-coded primary topic as either the first or the second most probable topic for each document in the sample. When doing so, the F1 scores improve considerably for several important climate-related themes (see Table 1). For instance, we observe a sizeable increase in the F1 scores for energy-related themes, with both Non-renewable and Renewable Energy registering values near 0.80. Similarly, we observe a considerable increase in the F1 scores for the Climate Science and Climate Impacts themes, as well as a dramatic improvement for Domestic climate politics and International security. Overall, while this analysis demonstrates a range of validity across the 23 meta-topics, we find reasonable predictive accuracy for key climate-related themes.

\section{Explaining coverage: the correlates of climate change reporting}

We now turn to examining the correlates of climate change coverage. What societal- and newspaper-level factors explain variation in coverage on key climaterelated issues in Russia? To examine this question, we focus on 23 newspapers for which sufficient data was available over the 2000 to 2014. These papers represent a substantial percentage of the overall circulation in Russia and include a representative cross-section of papers based on ownership structure, political ideology, and ties to the Russian central government (see appendix table A.2). The remainder of this section outlines our variables of interest, statistical methodology, and presents our main empirical findings.

\subsection{Outcome variables}

The 23 meta-topics in Table 1 offer a detailed set of themes for measuring the intensity of climate coverage. Yet, to keep the analysis manageable, we focus our attention on three sets of meta-topics that 1) cover salient themes that are important in the Russian climate change literature (Poberezhskaya 2014; Tynkkynen 2010; Wilson Rowe 2009; Yagodin 2010) and 2) exhibit reasonable levels of predictive accuracy ( $F 1$ top $2>0.70$ ). First, we examine the intensity of coverage for two key aspects of climate change by combining climate science and climate impacts (see Table 1) into climate science 86 impacts. This variable represents a core aspect of climate literacy and provides a useful means to gauge coverage of climate change fundamentals. Second, we combine international security and arctic politics into geopolitics, which centers on discussions of climate change in the context of international relations. Further, we seek to explain variation in how Russian newspapers have reported on climate change negotiations by investigating the international climate agreements meta-topic. Lastly, we investigate the variation in newspaper attention on energy-related themes within 
the context of climate change by combining non-renewable energy, renewable energy, and energy efficiency into energy issues. Time-series plots of these outcome variables over the period Q1/2000-Q2/2014 are illustrated in Figure ??, which can be found in ?? of the supplemental appendix.

The obvious next step involves determining an operational definition for the selected themes. As described in Boussalis and Coan (2016), there is no agreed upon "best" strategy for generating measures from underlying topic data and the appropriateness of a particular strategy is contingent on the research question of interest. Given the literature on Russian climate communication, our primary interest is in determining how papers frame the climate issue and whether the framing changes according to national- and newspaper-level factors. In particular, we examine how different papers make trade-offs when discussing different climate-related themes, focusing on the proportion of all words devoted to a particular meta-topic in Table 1 for each paper-quarter. As such, this measure allows us to examine under what context a particular paper discusses the issue of climate change.

\subsection{National and newspaper-level covariates}

We also focus on national and newspaper-level covariates considered important in the communications literature. Classifying Russian newspapers' ownership, ideology and their relations with the state has proven to be a difficult task for researchers, and as Koltsova (2006) notes due to the rapid and constant changes in the Russian media market, these variables often remain a mystery even to market actors. In order to eliminate as many coding inaccuracies as possible, we have consulted a range of sources including: web-pages of the studied newspapers, publicly available databases (e.g. media-atlas.ru, mediageo.ru) and relevant literature sources (e.g. Nenashev 2010, Strovskiy 2011, Zassoursky 2004). To account for national level variables which may influence newspaper coverage of climate change, we control for consumer prices and the occurrence of extreme temperature, drought and storm events. A list of the variables along with their levels and descriptions are presented in Table 2.

\subsection{Statistical methods}

The next challenge is finding a suitable statistical model to examine variation in climate coverage as a function of key covariates. We assume that decisions regarding climate coverage result from a mixture of two random processes: newspapers first decide whether to discuss the issue of climate change at a given point in time and next decide how much coverage to devote to a particular theme. More specifically, we model climate coverage using a mixture of a Bernoulli distribution for the decision to cover the issue at all and a beta distribution to represent coverage intensity (see the appendix for technical details). While a Bernoulli-beta mixture model offers a flexible approach to examining the skewed and zero-inflated proportions that are typical in our data, the standard setup ignores the clustering produced by examining a cross-section of newspapers over time. We thus extend the standard model to include random effects for both 


\begin{tabular}{|c|c|c|}
\hline Variable Label & Levels & Description \\
\hline \multirow[t]{4}{*}{ Ownership structure } & Business & $\begin{array}{l}\text { Ownership structure is dominated by the business } \\
\text { organisations with interests outside of the media market }\end{array}$ \\
\hline & State & Predominately state-owned newspapers \\
\hline & Journalist collective & $\begin{array}{l}\text { Predominately owned by people with main } \\
\text { interests in the media market }\end{array}$ \\
\hline & Political party & Owned by oppositional political parties \\
\hline \multirow[t]{2}{*}{ Energy } & Yes & Owners have interests in energy sector \\
\hline & No & No obvious connection with energy sector \\
\hline \multirow[t]{3}{*}{ Political spectrum } & Left & Supports or advocates socialist/communist ideas \\
\hline & Centre & $\begin{array}{l}\text { Supports or advocates ideas of political and economic } \\
\text { stability, and traditional values }\end{array}$ \\
\hline & Right & Supports or advocates ideas of capitalism and liberalism \\
\hline \multirow{2}{*}{ Kremlin affiliation } & Pro-Kremlin & Non-state owned paper supports government in power \\
\hline & Independent & $\begin{array}{l}\text { No obvious support for the government in power } \\
\text { from non-state owned paper }\end{array}$ \\
\hline Inflation & $\begin{array}{l}\text { Mean }=11.78 \\
S D=5.04\end{array}$ & $\begin{array}{l}\text { Average quarterly consumer prices (all items), } \\
\text { percentage change on the same period } \\
\text { of the previous year (OECD 2016). }\end{array}$ \\
\hline Disasters & $\begin{array}{l}\text { Mean }=0.67 \\
S D=1.00\end{array}$ & $\begin{array}{l}\text { Quarterly counts of extreme temperature, } \\
\text { drought and storm events (Guha-Sapir et al. 2015). }\end{array}$ \\
\hline
\end{tabular}

Table 2: National and newspaper-level variables and descriptions. Note: The identification of the Russian political spectrum is a complex task, as notions of the political "right", "centre" and "left" have been altered and even swapped over time (see more in Simonsen 2001). In this article we have adopted the most common interpretation of the concepts. Summary statistics and descriptions are also presented for Inflation and Disasters.

the newspaper ( $n=23$ papers) and time ( $t=58$ quarters). All of the models presented below are estimated using a fully Bayesian approach (see the appendix for additional details).

\subsection{Results}

We begin with the first step in the data generating process by examining the factors that influence whether or not a paper covers climate change at all in a particular quarter. Figure 2 provides estimates from a logistic regression for the decision to cover the climate issue, where the outcome is equal to 1 if a paper mentions climate change in a given quarter and zero otherwise. The figure plots the estimated coefficients (log odds) for each variable of interest based on the median posterior value, while also providing $90 \%$ credible intervals. To ease the interpretation, we set the baseline category to the group expected, a priori, to have the most overall coverage of climate change based on the past scholarship: left-leaning papers, owned by journalists, without a direct energy interest, and not beholden to the Kremlin (Poberezhskaya 2015). The results generally fit with expectations. The overall state of the economy - as measured by inflation - has the largest overall influence on the probability of covering the climate issue. Not surprisingly, when times are tough economically, climate change is less likely to appear in the news agenda: moving inflation from its minimum to maximum value - while fixing all other variables at constant values - leads to a 0.10 decline 


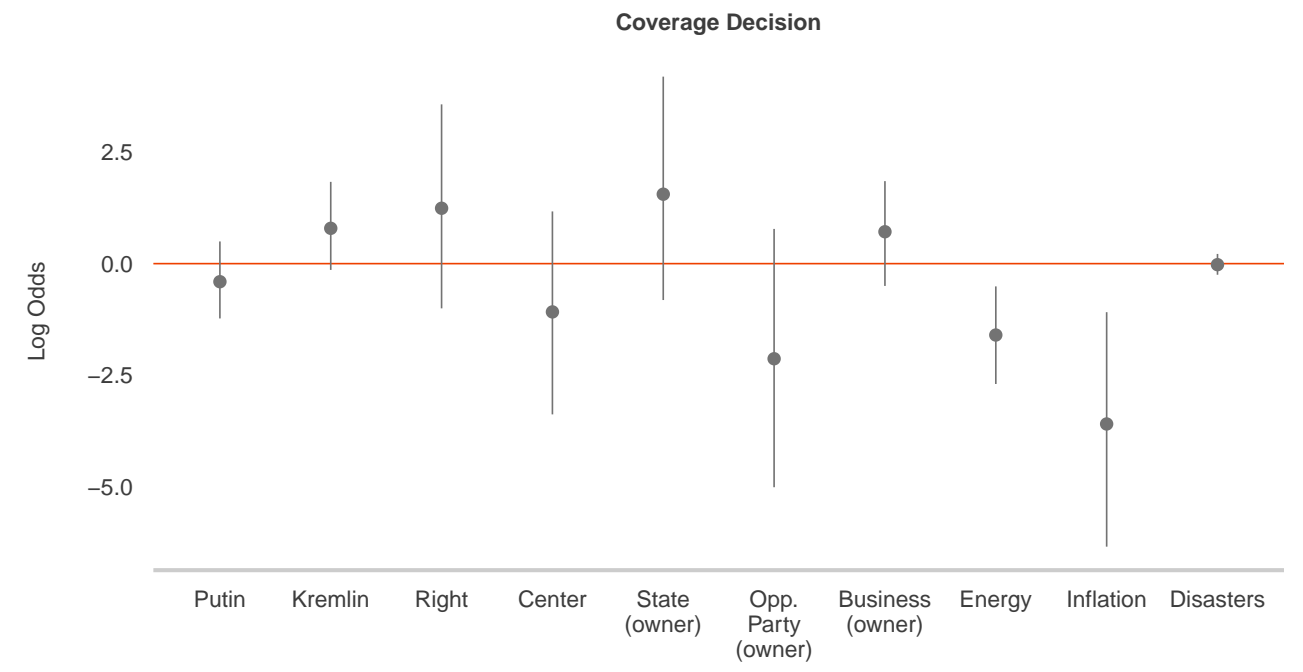

Figure 2: Explaining variation of any mention of climate change. Dots represent parameter estimates based on the posterior median; lines provide the $90 \%$ highest density intervals. The baseline represents the newspaper profile expected to cover climate change most frequently: left leaning, journalist-owned newspapers, with no direct energy interest, and not affiliated with the Kremlin. The estimated coefficient for the intercept (not shown) is 5.7 (HDI $=[2.8,8.5])$.

in the probability of covering climate change. This level of change, however, represents a considerable swing in economic conditions and, for more moderate changes (e.g., from the $1^{\text {st }}$ to the $3^{\text {rd }}$ quartile of inflation), inflation leads to a roughly $1 \%$ decline in discussing climate-related issues. Energy ownership also reduces the propensity of a newspaper to report on climate-related issues, with the likelihood of covering climate change again falling by roughly $1 \%$ for papers owned by an energy company. Lastly, opposition party papers are approximately $2 \%$ less likely to mention climate change at all - though, this estimate is quite uncertain. We do not find a significant difference in the likelihood of climate change coverage between Putin or Medvedev presidential periods. Further, we do not find a significant conditional relationship between presidential period and state-owned or Kremlin-loyal papers on the probability of covering climate change (not shown).

Examining mentions alone, however, offers little insight into how climate change is being covered in the Russian press. That is, if a paper decides to cover the climate issue, in what context do they do so? To examine this question, we use the relative measure of coverage intensity introduced in Section 4.1 and the mixed effects zero-inflated beta model outlined in Section 4.3. We begin 
with two central features of climate change communication-reporting on climate science 8 impacts. As demonstrated in Figure 3, we find support for the impact of national-level variables on coverage of climate science in the Russian press. Specifically, we find that if a paper covers climate change during times of high inflation, the discussion is less likely to be framed around climate science $(\log$-odds $=-1.03, \mathrm{CI}=[-1.96,-0.26])$. Moving inflation from one standard deviation above to one standard deviation below the mean leads to around an $8 \%$ decline in the likelihood of emphasizing climate science and impacts. Conversely, during periods with high instances of natural disaster, coverage is more likely to emphasize scientific discussion (log-odds $=0.07, \mathrm{CI}=[0.02,0.13])$. Here, moving from no extreme weather events to 4 extreme weather events (i.e., the maximum), increases the likelihood of framing discussion in terms of climate science and impacts by roughly $7 \%$. There does not seem to be a substantive presidential effect on how newspapers discuss climate science $\&$ impacts. Further, by and large, there is little evidence for newspaper-level effects. There are, however, several exceptions: right-leaning (log-odds $=-0.22, \mathrm{CI}=[-0.64,0.18]$ ) and opposition party papers (log-odds $=-0.40, \mathrm{CI}=[-0.93,0.11])$ are generally less likely to emphasize science, while state-owned newspapers are more likely to focus on science-related issues $(\log$-odds $=0.30, \mathrm{CI}=[-0.10,0.72])$ - though, again, uncertainty remains relatively high for these estimates.

Next, we move beyond science to issues associated with the political economy of climate change in Russia. Figure 3 provides estimates for our aggregate measure of geopolitics. As shown in the figure, both paper-level and nationallevel factors seem to play a role in the level of climate-related discussion devoted to geopolitical issues. Considering paper-level variables, energy ownership influences discussion of geopolitics, yet papers with energy interests are only less than $1 \%$ more likely to cover climate change in the context of international relations. Oppositional party papers are also more likely to frame climate coverage in the context of security concerns and international competition over the Arctic region $(\log$-odds $=0.52, \mathrm{CI}=[0.07,0.97])$. To a lesser extent, right-leaning and state-owned papers are more likely to cover climate change in the context of geopolitics - though, there is still a fair level of uncertainty associated with both estimates. And we continue to find evidence for the influence of economic conditions; when inflation is high, papers are more likely to frame the climate change debate in terms of geopolitical competition. Further, when disaggregating geopolitics into international security and arctic politics (not shown), we find that security is largely responsible for driving geopolitical frames. That is, the effects of energy and opposition party ownership as well as inflation are stronger when focusing on international security alone. There does seem to be a marginal presidential effect. Specifically, we find that during a Putin presidency, papers are less likely (log-odds $=-0.15, \mathrm{CI}=[-0.31,-0.01])$ to discuss climate change in the context of geopolitics, however the effect is quite small: newspapers under a Putin presidency are only $0.4 \%$ less likely to frame global warming in terms of geopolitical concerns.

The analysis next shifts to climate change discussions in the context of in- 


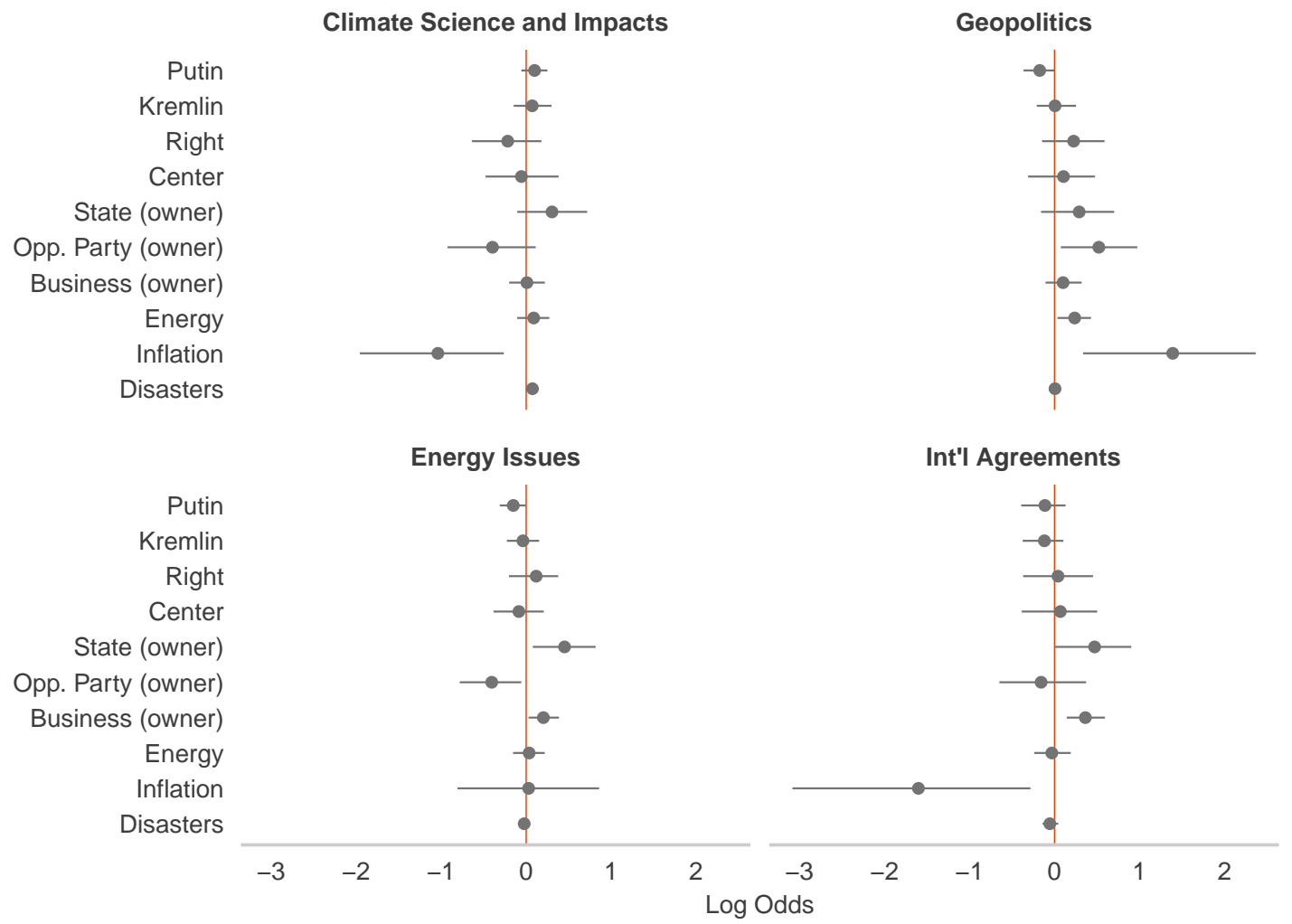

Figure 3: Coverage of specific climate-related issues. Dots represent the parameter estimates (posterior medians) from the zero-inflated beta regression model described in Section 4.3, and the lines once again represent the $90 \%$ HDI. We employ the same baseline as Figure 2 above and thus compare to a "high frequency" newspaper profile. The estimated intercepts (not shown) are as follows: climate science and impacts ($0.59,[-1.55,0.32])$, geopolitics $(-4.55,[-5.68,-3.48])$, energy issues $(-3.46,[-4.42,-2.60])$, and international agreements $(-2.22,[-3.74,-0.74])$.

ternational climate agreements. Again, economic hardship, as measured by inflation, has a negative impact on newspaper attention to climate change negotiations $(\log$-odds $=-1.60, \mathrm{CI}=[-3.08,-0.28])$. For instance, moving inflation from one standard deviation below its mean to one standard deviation above, decreases discussion on global warming negotiations by roughly $4 \%$. With respect to newspaper-level variables, the results suggest that state- $(\log$-odds $=0.47$, CI $=[0.0001,0.90])$ and business-owned newspapers (log-odds $=0.36, \mathrm{CI}=[0.14$, 0.59]) are more likely to frame global warming along the lines of climate diplomacy. Substantively, government ownership is associated with an approximate 
$5 \%$ increase in discussion, while business group ownership leads to a roughly $4 \%$ increase.

Lastly, we examine the extent to which newspapers frame climate coverage in terms of energy issues. Not surprisingly, business-owned newspapers are more likely to emphasize climate change in the context of energy issues (log-odds $=$ $0.20, \mathrm{CI}=[0.03,0.39])$. Yet, the strongest newspaper-level effects are observed for state-owned $(\log$-odds $=0.45, \mathrm{CI}=[0.08,0.82])$ and opposition party papers $(\log$-odds $=-0.40, \mathrm{CI}=[-0.78,-0.06])$. State-owned papers are approximately $2 \%$ more likely to highlight energy issues when covering global warming, while opposition party papers are $2 \%$ less likely to do so. When digging a bit deeper into these estimates, we find that attention devoted to renewable energy and energy efficiency play a particularly influential role. While we observe weak differences across papers for non-renewable energy, business- and state-owned papers have a strong positive influence on the likelihood of framing climate change in terms of "energy solutions," while opposition party outlets generally avoid discussion of these issues. We also find a negative effect of a Putin presidency on discussions of climate change with respect to energy issues (log-odds $=-0.17, \mathrm{CI}=$ $[-0.36,-0.002])$. However, yet again, this effect is substantively small: newspapers during a Putin presidency are $0.2 \%$ less likely to discuss climate change in the context of energy.

\section{Discussion}

Newspaper attention to climate change has risen steadily ever since the issue was identified as an international problem. A key question for both scholars of climate communication and Russian politics centers on the similarities and differences of Russian media coverage to other major actors in climate politics. We start by considering overall trends in coverage of the issue. Boykoff et al. (2015) demonstrates how interest by the global press increased rapidly starting in late 2006 and remained high for the following few years (see also Schmidt et al. 2013). This increase coincided with important events such as the release of the IPCC Fourth Assessment Report (AR4), the release of Al Gore's An Inconvinient Truth, and the awarding of the Nobel Peace Prize to Al Gore and the IPCC. There is another pronounced spike in attention in late 2009 that was triggered by the Copenhagen Conference (COP-15) on climate change and the "Climategate" scandal that preceded it. Our data suggest that Russian newspaper attention generally followed this pattern and, in particular, we find noticeable similarities between Russian coverage and that of the U.S. prestige press (see Figure 1). Yet, although the general trends are similar, there are several key differences. First, and perhaps most importantly, our analysis confirms that Russian newspaper coverage of climate change is relatively low in absolute terms (Poberezhskaya 2015). As demonstrated in Figure 1, a single major American newspaper (The New York Times) has published more articles on climate change than 23 of the most widely circulated papers in Russia. This low level of media attention may offer an explanation of why, when compared to 40 developing and developed 
nations, Russians are the most likely to report that "global climate change is not a serious problem" (Stokes et al. 2015). Second, while it seems that international media have picked up their interest in climate change in recent years and it has again acquired "celebrity status" (Pepermans and Maeseele 2014 p. 217; see also Fischer 2015), we find that Russian newspaper coverage has been steadily decreasing since 2010, with a pronounced drop starting in late 2013. This decline in coverage, moreover, corresponds to an increase in media attention associated with the Russian economic crisis and the onset of the security crisis in Ukraine.

Next, moving from trends in general attention to the correlates Russian climate coverage, we find that the state of the economy is crucial for predicting both whether climate change makes onto the media agenda and the way in which the issue is framed. When economic conditions are bad (as measured by high inflation), the media tend to avoid discussion of global warming and discuss climate change less in the context of science and international commitments, but more with respect to geopolitical concerns. In other words, instead of portraying climate change as an environmental problem, during hard times, the media will present climate change as just another item of discussion in the international arena, outlining opportunities which could be realized with a shift in global climate conditions. The influence of the economy on climate change communication has been identified in other countries as well. For instance, Carvalho (2005 , p. 21), in her analysis of the UK media points out how "free-market capitalism and neo-liberalism" restrict climate public discourse by encouraging the avoidance of problematic topics (e.g. restrictions of the economic growth in order to mitigate the problem). Holt and Barkemeyer (2012) also find negative effects of poor national economic performance on coverage of climate change in a large comparative study of 112 newspapers from 39 countries. As such, our analysis provides additional evidence that economic conditions plays an important role in governing the well-known "issue attention cycle" (Downs 1972).

Previous research also suggests that Russian media coverage of climate change is sensitive to political factors (Poberezhskaya 2015). Interestingly, our study provides little evidence of substantive variation in climate change coverage or attention to various climate change related themes between different presidential administrations (Putin vs. Medvedev). Further, we do not find conditional presidential administration effects on how state-owned newspapers or papers that are loyal to the Kremlin discuss climate change. That is, newspapers that are beholden to the government do not discuss global warming differently when Putin or Medvedev are serving as President. Also, non-state-owned newspapers that are loyal to the Kremlin do not seem to systematically differ from the baseline case in their reporting of global warming. These results contribute to the on-going academic debate on the role of the personality of the state leaders in shaping climate discussion in Russia (Henry and Sundstrom 2012). The weak evidence found in our study could be explained by the constant powerful impact of Putin's politics regardless of whether he is the Prime Minister or President. On the other hand, as Andonova (2008) states, Russian climate policy cannot simply be explained by the will of the executive but rather by a combination of 
various political processes.

We also find a much weaker role for natural disasters in explaining variation in coverage of global warming and framing of the issue by the Russian press. Our results indicate that the occurrence of climate-related natural hazards, such as extreme temperature, drought and storms, are associated with an increase in discussions of climate science and climate impact. However, we find little evidence of a disaster effect on overall coverage rates or discussion of energy, geopolitics, or international climate negotiations. Given these findings, we might speculate that natural disasters bring climate change to the realm of popular scientific discourse by trying to explain events, providing advice or raising the alarm of the observed (or possible) negative outcomes. This correlates with Wilson Rowe's (2013) argument that while Russian climate scientists rarely act as "policy entrepreneurs" but rather concentrate on educating policy-makers and the public by explaining the scientific side of the problem.

While national-level factors are predictive, paper-level characteristics also play a role, with papers varying in how they frame the issue. In terms of newspapers' political affiliation and ownership, there is some evidence to suggest that the media outlets on the political right are less likely to address climate change in terms of science and impact. However, when such papers do discuss climate science, they typically provide a rational account of anthropogenic climate change with descriptions of its cause and consequences. Newspapers on the extreme political left and right bring into their discussion of climate science sensationalism and in some cases governmental critique:

The region is not yet experiencing climatic difficulties, and its problems are due to the irrational management of agricultural production and water waste (Pravda 9/01/2004)

On the other hand, newspapers of the political center express a range of views on the issue. Moreover, when taking a closer look at the corpus-particularly among state-owned papers - there are clear instances of climate scepticism. For instance:

Global warming will soon finish (Rossiiskaia gazeta 19/09/2007)

Maybe the president's advisor, Andrey Illarionov [an infamous Russian climate sceptic], is right in his stubborn resistance to the Kyoto Protocol? (Rossiiskaia gazeta 31/08/2005)

This finding also correlates with the development of the state's climate policy, which until a few years ago was dominated by sceptical discourse. Newspapers with connections to the energy sector mostly tend to look at the problem from the position of international security which often involves discussion of Russian energy interests. For instance, when surveying climate-related articles in our corpus with a high probability of containing a topic related to geopolitics, we found numerous discussions of global competition for the Arctic's resources by papers with energy interests: 
Russia continues to strengthen its positions in the unavoidable division of the Arctic [...] The Arctic shelf presumably contains up to 25 per cent of the world's hydrocarbon reserves, and in connection with global warming, the possibility of their extraction becomes real. (Izvestiia 24/12/2008)

A similar pattern was detected with oppositional and right-wing newspapers also being more likely to discuss climate change in relation to international relations. However, these papers differ slightly in their approach, where the media outlets from the political right provide a more straightforward account of the potential losses and gains in the geopolitics of climate change. In contrast, newspapers belonging to the extreme left and right tend to briefly mention climate change in their elaborate analyses of global politics:

Today Anglophone plans are implemented under the guise of a stateless "globalization" and ultra-Malthusian scam called "global warming," pushed by former US Vice President Al Gore' (Zavtra 18/4/2007)

Our study also demonstrates that ownership structures impact the way Russian newspapers approach energy-related topics, with business-owned and stateowned papers not only mentioning climate change within energy discussions more often, but also paying greater attention to "energy solutions" (e.g., renewables and energy efficiency). Izvestiia, for example, has pointed to American excess when discussing how, "until recently uneconomical and environmentally 'dirty' cars were the most popular choice among American consumers" (Izvestiia $13 / 02 / 2004)$. Business owned papers were likely to express an interest in energy conservation as well:

The country has a long-term commitment to provide energy for export. It is currently almost the only real means of Russia's political influence [...] Therefore, Russia has to seriously think about a more rational use of its energy resources, as well as of the use of energysaving technologies' (Kommersant 19/10/2005).

A similar pattern was noticed in how these types of newspapers tackle the topic of international environmental agreements by strategically assessing Russia's gains and losses from the process:

Russia needs to fit into a new global climate order. While Russia does not persevere in promoting their GHG emission reduction projects, in April 2009 a new US administration has claimed its global leadership in the fight to preserve the environment and to development the ideas of global "climate control" (Rossiiskaia gazeta 6/05/2009).

Our data also show how media coverage is influenced by similar considerations as the Russian state's climate policy. Interest in the issue began to "take off" after policy makers began to consider mitigation efforts for their potential benefits to the country (e.g. introducing renewables into the national market in order to 
increase fossil fuel exports, reducing energy costs, attracting investments, etc.). Though this approach may be seen as "green washing," in the Russian case, it offers a tangible - and even optimal - solution for attracting the interest of the state. Moreover, this approach allows for increased attention without causing a political confrontation among key stakeholders by demanding economic sacrifice and allocating blame for over-reliance on the fossil fuel industry.

\section{Conclusion}

This study offers a systematic and comprehensive analysis of Russian newspaper coverage and discussion of climate change since the end of the Yeltsin era. Employing methods from machine learning and natural language processing, we have been able to classify a large set of climate-relevant newspaper articles into distinct themes related to global warming. Using a sub-sample from these data, we investigate whether a set of national and newspaper-level factors help explain variation in Russian newspaper coverage of climate change as well as how newspapers frame the issue over the period 2000-2014. Overall, our analysis has helped us to understand when climate change is more or less likely to enter Russian public discourse (the first level of the agenda-setting function of mass media (McCombs and Shaw 1972), and how newspapers cover climate change during its peaks and lows of attention (the second level of media agenda-setting function (ibid)). We find that national level factors such as the state of the economy are highly predictive of coverage, while paper-level indicators are less consistently related to changes in the media discourse.

While the current study focuses on the issue of climate change, our empirical findings raise broader questions on the political economy of media production in Russia. First, it is clear from our analysis that economic considerations - general economic conditions and energy interests - play a vital role in what the media choose to present. Second, it is striking just how little variation one observes across newspapers with very different underlying ideologies and ownership structures. These findings, moreover, are at odds with scholarship based on Western countries - primarily in the US and UK - which suggests that the ideological predispositions of media outlets significantly influence which issues are discussed and how these issues are framed (for ideology and climate change coverage, see for instance Carvalho 2007, Schmid-Petri et al. 2015), though there is evidence that Dutch newspapers are also not affected by ideological disposition on the issue of climate change (Dirikx and Gelders 2010). Similarly, changes at the executive level - from an arguably skeptical Putin to the environmentally-minded Medvedev - did not appear to systematically alter how the media covered climate change. And though speculative, the consistency of coverage across (seemingly) diverse media outlets underscores the challenge of getting the issue of climate change onto the political agenda and perhaps offers an observable implication of wider changes in the Russian media market, which has become increasingly centralized and controlled over the last decade (Lehtisaari 2015). While it is difficult to know the extent to which these findings generalize to other political 
issues, the analysis does raise questions regarding how media operate in Russia and the ways in which corporate elite influence the media landscape.

The study does, however, have a number of limitations. First, our analysis does not consider the sentiment and tone of the newspaper articles. For instance, when a paper is discussing climate science, we cannot determine whether the author is being skeptical or dismissive. This is an important drawback which should be addressed in future work. Second, the study relies exclusively on print media, while not including television, radio, and online media, which might present a more complete picture of climate discourse in Russia. Lastly, due to data availability, we were forced to exclude newspaper articles from the Yeltsin era. We, therefore, are not able to generalize our findings on newspaper coverage to the 1990 s.

Nevertheless, our results offer a number of valuable insights into climate change communication in Russia. During the Paris COP-21 meeting in September 2015, President Putin re-affirmed Russia's pledge to contribute to the global fight against climate change through further GHG reductions. Some have thought that Putin could have been more ambitious in his claim since a reduction of 25$30 \%$ in GHG emissions to the 1990 level will not revolutionize Russia's energy market. On the other hand, considering Russia's ambiguous history of climate change policy, any move forward should be treated as a positive development where the interested parties (climatologists, environmental activists and the international community) should not only understand all of the intricacies of Russian climate discourse but should also learn how Russian media can be utilized in order to popularize climate-related discussions. In other words, focus should be shifted to when climate is more likely to receive attention from the Russian media and how it can be framed in order to involve various media actors regardless of their ownership structure, energy interests and political affiliation. It is our belief that this study makes a substantial contribution in this regard and can also be utilized as a platform for further inquiries into Russian public discourse of climate change-related topics. 


\section{References}

Afionis, S., Chatzopoulos, I., 2010. Russia's role in unfccc negotiations since the exit of the united states in 2001. International Environmental Agreements: Politics, Law and Economics 10 (1), 45-63.

Ali, O., Flaounas, I., Bie, T. D., Mosdell, N., Lewis, J., Cristianini, N., September 2010. Automating news content analysis: An application to gender bias and readability. In: Workshop on Applications of Pattern Analysis (WAPA). JMLR: Workshop and Conference Proceedings, pp. 36-43.

Andonova, L. B., 2008. The climate regime and domestic politics: the case of russia. Cambridge Review of International Affairs 21 (4), 483-504.

Antilla, L., 2008. Self-censorship and science: a geographical review of media coverage of climate tipping points. Public Understanding of Science.

Bailey, A., Giangola, L., Boykoff, M. T., 2014. How grammatical choice shapes media representations of climate (un) certainty. Environmental Communication 8 (2), 197-215.

Barriopedro, D., Fischer, E. M., Luterbacher, J., Trigo, R. M., García-Herrera, R., 2011. The hot summer of 2010: redrawing the temperature record map of europe. Science 332 (6026), 220-224.

Beck, U., 1992. Risk society: Towards a new modernity, published in association with theory, culture \& society.

Becker, J., 2004. Lessons from russia a neo-authoritarian media system. European Journal of Communication 19 (2), 139-163.

Bedritsky, A., 2014. Zayavkenie spetspredstavitelya prezidenta po voprosam klimata aleksandra bedritskogo.

URL http://state.kremlin.ru/news/47115/print

Bell, A., 1994. Climate of opinion: public and media discourse on the global environment. Discourse \& Society 5 (1), 33-64.

Blei, D. M., 2012. Probablistic topic models. Communications of the ACM 55 (4), 77-84.

Blei, D. M., Ng, A. Y., Jordan, M. I., 2003. Latent dirichlet allocation. Journal of Machine Learning Research 3, 993-1022.

Boussalis, C., Coan, T. G., 2016. Text-mining the signals of climate change doubt. Global Environmental Change 36, 89-100.

Boyce, T., Lewis, J., 2009. Climate change and the media. Vol. 5. Peter Lang.

Boykoff, J., 2012. Us media coverage of the cancun climate change conference. PS: Political Science \& Politics 45 (02), 251-258. 
Boykoff, M., 2007a. Flogging a dead norm? newspaper coverage of anthropogenic climate change in the united states and united kingdom from 2003 to 2006. Area 39 (4), 470-481.

Boykoff, M., Boykoff, J., 2004. Balance as bias: global warming and the us prestige press. Global Environmental Change 14, 125-136.

Boykoff, M., Daly, M., Gifford, L., Luedecke, G., McAllister, L., Nacu-Schmidt, A., Andrews, K., 2015. World newspaper coverage of climate change or global warming, 2004-2015. center for science and technology policy research, cooperative institute for research in environmental sciences, university of colorado. URL http://sciencepolicy.colorado.edu/media_coverage

Boykoff, M., Rajan, S., 2007. Signals and noise: Mass-media coverage of climate change in the usa and the uk. EMBO Reports 8 (3), 207-211.

Boykoff, M. T., 2007b. Flogging a dead norm? newspaper coverage of anthropogenic climate change in the united states and united kingdom from 2003 to 2006. Area 39 (4), 470-481.

Boykoff, M. T., Boykoff, J. M., 2007. Climate change and journalistic norms: A case-study of us mass-media coverage. Geoforum 38 (6), 1190-1204.

Broadcasting Board of Governors, 2014. Contemporary media use in russia. URL https://www.bbg.gov/wp-content/media/2014/02/Russiaresearch-brief.pdf

Butler, C., Pidgeon, N., 2009. Media communications and public understanding of climate change: reporting scientific consensus on anthropogenic warming. Climate change and the media, 43-58.

Carvalho, A., 2005. Representing the politics of the greenhouse effect: Discursive strategies in the british media. Critical Discourse Studies 2 (1), 1-29.

Carvalho, A., 2007. Ideological cultures and media discourses on scientific knowledge: re-reading news on climate change. Public understanding of science $16(2), 223-243$.

Carvalho, A., Burgess, J., 2005. Cultural circuits of climate change in uk broadsheet newspapers, 1985-2003. Risk analysis 25 (6), 1457-1469.

Coyne, C. J., Leeson, P. T., 2009. Media as a mechanism of institutional change and reinforcement. Kyklos 62 (1), 1-14.

Davidsen, C., Graham, D., 2014. Newspaper reporting on climate change, green energy and carbon reduction strategies across canada 1999-2009. American Review of Canadian Studies 44 (2), 151-168. 
Davydova, A., 2015. Russia's forest overlooked in climate change fight. URL http://www.trust.org/item/20150115092042-mtqjn/?source= jtOtherNews 1

Deloitte CIS Research Centre, 2016. Media consumption in russia: Key trends. URL https://www2.deloitte.com/content/dam/Deloitte/ $\mathrm{ru} /$ Documents/technology-media-telecommunications/mediaconsumption-in-russia-2015-en.pdf

Dirikx, A., Gelders, D., 2009. Global warming through the same lens: An explorative framing study in dutch and french newspapers. status: published.

Dirikx, A., Gelders, D., 2010. Ideologies overruled? an explorative study of the link between ideology and climate change reporting in dutch and french newspapers. Environmental Communication 4 (2), 190-205.

Doulton, H., Brown, K., 2009. Ten years to prevent catastrophe?: Discourses of climate change and international development in the uk press. Global Environmental Change 19 (2), 191-202.

Downs, A., 1972. The issue-attention cycle and the political economy of improving our environment. The Political Economy of Environmental Control (University of California Press, Berkeley), 9-34.

Dunlap, R. E., Jacques, P. J., 2013. Climate change denial books and conservative think tanks: exploring the connection. American Behavioral Scientist, $1-33$.

Elsasser, S. W., Dunlap, R. E., 2013. Leading voices in the denier choir: Conservativecolumnists' dismissalof global warming and denigration of climate science. American Beh 57 (6), 754-776.

Fischer, D., 2015. Back in the headlines: Climate coverage returns to its 2009 peak. The Daily Climate.

URL http://www.dailyclimate.org/tdc-newsroom/2015/01/climatechange-coverage-2014

Grabel'nikov, A., 2001. Rabota Zhurnalista v Presse. Moscow.

Grimmer, J., King, G., 2011. General purpose computer-assisted clustering and conceptualization. Proceedings of the National Academy of Science Inagural Articles, 1-8.

Grimmer, J., Stewart, B. M., 2013. Text as data: The promise and pitfalls of automatic content analysis methods for political texts. Political Analysis 21 (3), 267-297.

Grundmann, R., Scott, M., 2012. Disputed climate science in the media: Do countries matter? Public Understanding of Science, 0963662512467732. 
Guha-Sapir, D., Below, R., Hoyois, P., 2015. Em-dat: International disaster database. Univ. Cathol. Louvain, Brussels: Belgium. www. em-dat. net. Accessed.

Hanson, P., 2010. Developments in Russian Politics 7. Durham: Duke University Press, Ch. Managing the economy, pp. 188-205.

Henry, L. A., 2010. Between transnationalism and state power: the development of russia's post-soviet environmental movement. Environmental Politics 19 (5), 756-781.

Henry, L. A., Sundstrom, L. M., 2012. Russia's climate policy: International bargaining and domestic modernisation. Europe-Asia Studies 64 (7), 12971322 .

Holt, D., Barkemeyer, R., 2012. Media coverage of sustainable development issues-attention cycles or punctuated equilibrium? Sustainable development $20(1), 1-17$.

Inglehart, R., 1995. Public support for environmental protection: Objective problems and subjective values in 43 societies. PS: Political Science \& Politics 28 (01), 57-72.

Koltsova, O., 2006. News media and power in Russia. Routledge.

Lehtisaari, K., 2015. Market and Political Factors and the Russian Media. Reuters Institute for the Study of Journalism Working Paper.

Levin, K., Damassa, T., 2015. Russia's new climate plan may actually increase emissions.

URL http://www.wri.org/blog/2015/04/russia $\%$ E2\%80\%99s-newclimate-plan-may-actually-increase-emissions

Li, Y., Johnson, E. J., Zaval, L., 2011. Local warming daily temperature change influences belief in global warming. Psychological Science.

Lipman, M., McFaul, M., 2001. "managed democracy" in russia putin and the press. The Harvard International Journal of Press/Politics 6 (3), 116-127.

Lockwood, A., 2009. Preparations for a post-kyoto media coverage of uk climate policy. Climate Change and the Media. Peter Lang: Oxford.

Lyytimäki, J., 2011. Mainstreaming climate policy: the role of media coverage in finland. Mitigation and Adaptation Strategies for Global Change 16 (6), 649-661.

McCombs, M. E., Shaw, D. L., 1972. The agenda-setting function of mass media. Public opinion quarterly 36 (2), 176-187. 
Mickiewicz, E. P., 1999. Changing channels: Television and the struggle for power in Russia. Duke University Press.

Mikhaylov, S., Laver, M., Benoit, K. R., 2012. Coder reliability and misclassification in the human coding of party manifestos. Political Analysis 20 (1), $78-91$.

Monaghan, A., 2012. The vertikal: power and authority in russia. International Affairs 88 (1), 1-16.

Nelkin, D., 1987. Selling science. how the press covers science and technology. New York: Freeman, 19871.

Nenashev, M., 2010. Illyuzii Svobody. Rossiyskie SMI v Epokhy Peremen (19852009). Moscow: Logos.

Newell, P., 2006. Climate for change: Non-state actors and the global politics of the greenhouse. Cambridge University Press.

Nissani, M., 1999. Media coverage of the greenhouse effect. Population and Environment 21 (1), 27-43.

OECD, 2016. Consumer prices. Main Economic Indicators (database).

URL http://www.oecd-ilibrary.org/economics/data/main-economicindicators/price-indices_data-00047-en

Olausson, U., 2009. Global warming - global responsibility? media frames of collective action and scientific certainty. Public Understanding of Science.

Olausson, U., Berglez, P., 2014. Media and climate change: Four long-standing research challenges revisited. Environmental Communication 8 (2), 249-265.

Painter, J., Ashe, T., 2012. Cross-national comparison of the presence of climate skepticism in the print media in six countries, 2007-10. Environmental Research Letters 7, 1-8.

Pepermans, Y., Maeseele, P., 2014. Democratic debate and mediated discourses on climate change: From consensus to depoliticization. Environmental Communication 8 (2), 216-232.

Poberezhskaya, M., 2014. Media coverage of climate change in russia: Governmental bias and climate silence. Public Understanding of Science, 96-111.

Poberezhskaya, M., 2015. Communicating Climate Change in Russia: state and propaganda. Rout.

Quinn, K. M., Monroe, B. L., Colaresi, M., Crespin, M. H., Radev, D. R., 2010. How to analyze political attention with minimal assumptions and costs. American Journal of Political Science 54 (1). 
Rapley, C., De Meyer, K., 2014. Climate science reconsidered. Nature Climate Change 4 (9), 745-746.

Rowe, E. W., 2013. Russian climate politics: When science meets policy. Springer.

Sakwa, R., 2010. The crisis of Russian democracy: the dual state, factionalism and the Medvedev succession. Cambridge University Press.

Schäfer, M. S., Ivanova, A., Schmidt, A., 2014. What drives media attention for climate change? explaining issue attention in australian, german and indian print media from 1996 to 2010. International Communication Gazette 76 (2), $152-176$.

Schmid-Petri, H., Adam, S., Schmucki, I., Häussler, T., 2015. A changing climate of skepticism: The factors shaping climate change coverage in the us press. Public Understanding of Science, 0963662515612276.

Schmidt, A., Ivanova, A., Schäfer, M. S., 2013. Media attention for climate change around the world: A comparative analysis of newspaper coverage in 27 countries. Global Environmental Change 23 (5), 1233-1248.

Scruggs, L., Benegal, S., 2012. Declining public concern about climate change: Can we blame the great recession. Global Environmental Change.

Shanahan, J., Good, J., 2000. Heat and hot air: Influence of local temperature on journalists' coverage of global warming. Public understanding of science 9 (3), 285-295.

Shrestha, S., Burningham, K., Grant, C. B., 2014. Constructions of climate change on the radio and in nepalese lay focus groups. Environmental Communication 8 (2), 161-178.

Shum, R. Y., 2012. Effects of economic recession and local weather on climate change attitudes. Climate Policy 12 (1), 38-49.

Simonsen, S. G., 2001. Nationalism and the russian political spectrum: locating and evaluating the extremes. Journal of Political Ideologies 6 (3), 263-288.

Stokes, B., Wike, R., Carle, J., 2015. Global concern about climate change, broad support for limiting emissions u.s., china less worried; partisan divides in key countries.

URL http://www.pewglobal.org/2015/11/05/global-concern-aboutclimate-change-broad-support-for-limiting-emissions /

Strovskiy, D., 2011. Otechestvennaya Zhurnalistika Noveyshego Perioda. UnitiDana. 
Taylor, N., Nathan, S., 2002. How science contributes to environmental reporting in british newspapers: a case study of the reporting of global warming and climate change. Environmentalist 22 (4), 325-331.

Toepfl, F., 2013. Why do pluralistic media systems emerge? comparing media change in the czech republic and in russia after the collapse of communism. Global Media and Communication, 1742766513504176.

Tynkkynen, N., 2010. A great ecological power in global climate policy? framing climate change as a policy problem in russian public discussion. Environmental Politics 19 (2), 179-195.

UNFCCC, 2014. National Inventory Submission 2014.

Voltmer, K., 2000. Constructing political reality in russia: Izvestiya - between old and new journalistic practices. European Journal of Communication 15 (4), 469-500.

White, S., Oates, S., 2003. Politics and the media in postcommunist russia. Politics 23 (1), 31-37.

Wilson Rowe, E., 2009. Who is to blame? agency, causality, responsibility and the role of experts in russian framings of global climate change. Europe-Asia Studies 61 (4), 593-619.

Yagodin, D., 2010. Russia: Listening to the wind-clientelism and climate change. Global climate, local journalism: A transnational study of how media make sense of climate summits. Bochum, Germany: ProjektVerlag.

Yanitsky, O., 2012. The 2010 wildfires in russia: An ecosociological analysis. Sociological research 51 (2), 57-75.

Young, L., Soroka, S., 2012. Affective news: The automated coding of sentiment in political texts. Political Communication 29 (2), 205-231. URL http://dx.doi.org/10.1080/10584609.2012.671234

Zassoursky, I., 2001. Sistema Sredstv Massovoy Informatsii Rossii. Moscow.

Zassoursky, I., 2004. Media and power in post-Soviet Russia. ME Sharpe.

Zaval, L., Keenan, E. A., Johnson, E. J., Weber, E. U., 2014. How warm days increase belief in global warming. Nature Climate Change 4 (2), 143-147. 